\title{
Copper Toxicity in Capsicum annuum: Superoxide Dismutase and Catalase Activities, Phenolic and Protein Amounts of in-vitro-Grown Plants
}

\author{
Cemil Islek ${ }^{1}$ Bengu Turkyilmaz Unal ${ }^{2 *}$ \\ 'Biology Department, Faculty of Arts and Science, Nigde University, Nigde, Turkey \\ ${ }^{2}$ Plant and Animal Production Department, Ulukısla Vocational School, Nigde University, Nigde, Turkey
}

Received: July 13, 2015

Accepted: August 8, 2015

\begin{abstract}
To determine some physiological and biochemical changes in Capsicum annuum L. grown in vitro, the effects of different $\mathrm{Cu}$ concentrations on this plant were investigated. $\mathrm{Cu}$ was applied in the form of $\mathrm{Cu}$ sulfate $\left(\mathrm{CuSO}_{4}\right)$ in three levels $(0,0.1$, and $0.2 \mathrm{mM})$ and at three times (days 8,10 , and 12$)$. With Cu treatments, superoxide dismutase (SOD), catalase (CAT) activities, and total phenolic compound amounts increased compared to the control. The protein amount gradually declined with increasing $\mathrm{Cu}$ concentrations. This study demonstrated that Capsicum annuum L. is quite tolerant of $\mathrm{Cu}$ and mobilizes catalase, superoxide dismutase, and phenolic compounds in order to mitigate $\mathrm{Cu}$-stress damage.
\end{abstract}

Keywords: abiotic stress, antioxidant enzyme, heavy metal, in vitro, pepper

\section{Introduction}

Heavy metals are defined as that group of elements that have specific weights higher than about $5 \mathrm{~g} / \mathrm{cm}^{3}$. A number of them (Co, Fe, Mn, Mo, Ni, $\mathrm{Zn}, \mathrm{Cu}$ ) are essential micronutrients and are required for normal growth and take part in redox reactions, electron transfers, and other important metabolic processes in plants [1].

Copper $(\mathrm{Cu})$ is a ubiquitous pollutant in the environment due to the emissions and atmospheric deposition of metal dust released by human activities. In addition, soils may contain elevated levels of $\mathrm{Cu}$ because of its widespread use as a pesticide, land application of sewage sludge, and mining and smelting activities [2].

$\mathrm{Cu}$ is an essential micronutrient for normal growth and development of plants, although it is also potentially toxic

*e-mail: bturkyilmaz@nigde.edu.tr
[3]. $\mathrm{Cu}$ participates in numerous physiological processes; however, as a redox active transition metal, excess $\mathrm{Cu}$ causes oxidative stress by generating free radicals via HaberWeiss and Fenton reactions at higher-than-optimal concentrations $[4,5]$. Also, excessive $\mathrm{Cu}$ can interfere with numerous physiological processes such as enzyme activity (i.e. ascorbate peroxidase, glutathione reductase, and superoxide dismutase), DNA alterations, protein oxidation, and membrane integrity - all of which can lead to growth inhibition of plants $[2,6,7]$.

Capsicum annuum L. is an economically important crop plant belonging to the family Solanaceae, and two main consumption types of pepper spice and vegetable are prevalent throughout the world [8]. It is an annual herbaceous plant that grows to a height of $30-90 \mathrm{~cm}$ and bears many-seeded fruit, usually borne singly or occasionally in clusters at the nodes. Fruit is extremely variable in size, shape, and color (ranging from blue to green, orange, red, 
yellow, violet, cream, white, and black) [9]. Peppers are a good source of vitamins $\mathrm{C}$ and $\mathrm{E}[10,11]$, as well as provitamin $\mathrm{A}$ and carotenoid compounds with well-known antioxidant properties $[12,13]$. Hot cultivars are rich in capsaicinoid alkaloids with pharmacological properties that give pepper fruit its specific taste $[11,14]$. Also present are flavonoids and phenolic compounds [15].

Capsicum annum L. is a very important agricultural crop grown in the field in Kahramanmaras, Gaziantep, Urfa, Diyarbakir, Adiyaman, and Hatay, and in greenhouse production in Antalya, Icel, Mugla, and Izmir in Turkey [16], but its yield is affected by numerous limiting factors [17], including diseases. Bacterial spots caused by Xanthomonas axonopodis pv. vesicatoria bacteria is considered to be one of the most destructive diseases in sweet peppers $[18,19]$. In these regions, cupreous preparations are used against this disease and their unnecessary or excessive use leads to stress, and some morphological, physiological, and biochemical changes in pepper plants [19, 20].

In this study, the effects of $\mathrm{Cu}$ on the content of total phenolics and protein, and the activities of catalase and superoxide dismutase enzymes in pepper were investigated. It was determined how some physiological and biochemical parameters were changed due to $\mathrm{Cu}$ concentrations.

\section{Material and Methods}

\section{Plant Material}

Seeds of C. annuum L. (Maraş-1) were obtained from the East Mediterranean Transitional Zone Agricultural Research Station.

\section{Culture Conditions}

Seeds of $C$. annuum L. were sterilized with $70 \%$ ethanol for three minutes and sodium hypochlorite for 20 minutes followed by washing with sterile distilled water. C. annuum seedlings were germinated in Murashige and Skoog's (MS) medium [21] without hormones. Hypocotyle explants of seedlings were taken into MS medium $(0.1 \mathrm{mg} / \mathrm{L}$ kinetin, $1 \mathrm{mg} / \mathrm{L} 2.4 \mathrm{D}, 3 \%$ sucrose and $0.7 \%$ agar) to produce callus tissue at $25^{\circ} \mathrm{C}$. Callus tissues were subcultured two times and taken into liquid medium (MS medium without agar) to produce cell suspensions in $100 \mathrm{ml}$ erlenmeyer flasks. The cultures were incubated on a shaker at $110 \mathrm{rpm}$ and $25^{\circ} \mathrm{C}$ [22]. Experiments were carried out in $100 \mathrm{ml}$ erlenmeyer flasks containing $40 \mathrm{ml}$ of fresh medium. Each flask was inoculated with $1 \mathrm{~g}$ fresh weight of cells. After 14 days of growth, $0,0.1 \mathrm{mM} \mathrm{CuSO}_{4}$ (added to the medium as elicitors to enhance the capsaicin production of pepper), and $0.2 \mathrm{mM} \mathrm{CuSO}_{4}$ were added. The cultures were maintained on an orbital shaker at $25^{\circ} \mathrm{C}$ for $8 \mathrm{~d}$., $10 \mathrm{~d}$., and $12 \mathrm{~d}$.

\section{Physiological and Biochemical Analyses}

Cell samples were collected after incubation. Total protein amount was determined according to Bradford's method [23]. Superoxide dismutase activity (SOD) assay was based on the method of Beauchamp and Fridovich [24], and catalase activity (CAT) was estimated according to the method of Bergmeyer [25]. Total phenolic content of callus was determined using the Folin-Ciocalteu assay [26]. Experimental data were analyzed with Tukey test at $\mathrm{P}<0.05$ level. Standard errors $( \pm)$ are calculated [27].

\section{Results and Discussion}

Excessive $\mathrm{Cu}$ can interfere with numerous physiological processes such as photosynthesis, pigment synthesis, nitrogen and protein metabolism, membrane integrity, and mineral uptake, since $\mathrm{Cu}$ can inactivate and disturb protein structures as a result of unavoidable binding to proteins [28].

In the current study, the total protein amounts decreased with $\mathrm{CuSO}_{4}$ treatments to the control in all treatment days (Fig. 1). The greatest reduction in protein amount was $75.924 \%$ at $0.2 \mathrm{mM} \mathrm{CuSO}_{4}$ on day 10 . These results are in agreement with $\mathrm{Hou}$ et al. [29], who showed that $\mathrm{CuSO}_{4}$ treatment negatively affects the soluble protein and photosynthetic pigments of duckweed.

It is well known that transition metals like $\mathrm{Cu}$ catalyze the formation of hydroxyl radicals $(\mathrm{OH} \cdot)$ from the nonenzymatic chemical reaction between superoxide $\left(\mathrm{O}_{2}^{-}\right)$and $\mathrm{H}_{2} \mathrm{O}_{2}$ (Haber-Weiss reaction) [30]. Hence, the presence of excess $\mathrm{Cu}$ can cause oxidative stress in plants and subsequently increase the antioxidant responses due to increased production of highly toxic oxygen-free radicals. Accordingly, it was observed that excess $\mathrm{Cu}$ in plants leads to oxidative stress-inducing changes in the activity and content of some components of the antioxidative pathways (i.e., ascorbate peroxidase (APX), monodehydroascorbate reductase (MDHAR), dehydroascorbate reductase (DHAR), glutathione reductase (GR), superoxide dismutases (SODs),

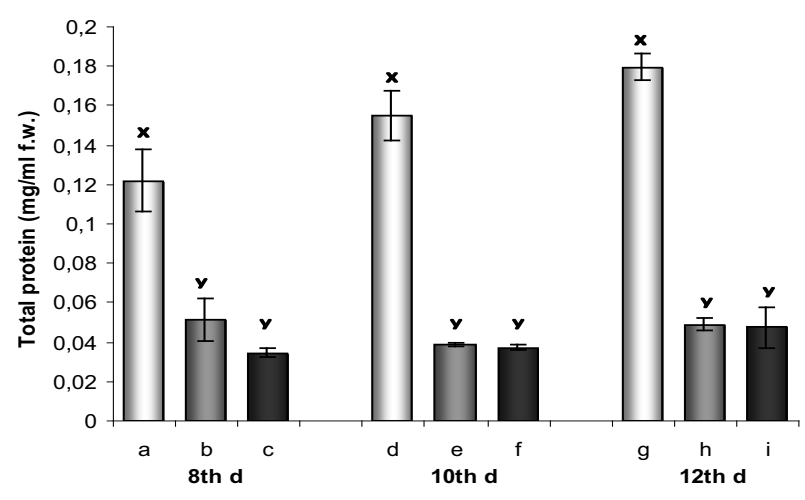

Fig. 1. Effects of $\mathrm{CuSO}_{4}$ at different concentrations on the amount of total protein in the cells of Capsicum annuum L. in different time.

a) Control, b) $0.1 \mathrm{mM} \mathrm{CuSO}$, c) $0.2 \mathrm{mM} \mathrm{CuSO}_{4}$ day 8; d) Control, e) $0.1 \mathrm{mM} \mathrm{CuSO}$, f) $0.2 \mathrm{mM} \mathrm{CuSO}_{4}$ day 10; g) Control, h) $0.1 \mathrm{mM} \mathrm{CuSO}_{4}$, i) $0.2 \mathrm{mM} \mathrm{CuSO}_{4}$ day 12 . Vertical bars represent $\mathrm{SE}(\mathrm{n}=4)$. Same letters are not significantly different at $\mathrm{p}<0.05$ on each treatment day (Tukey test) 


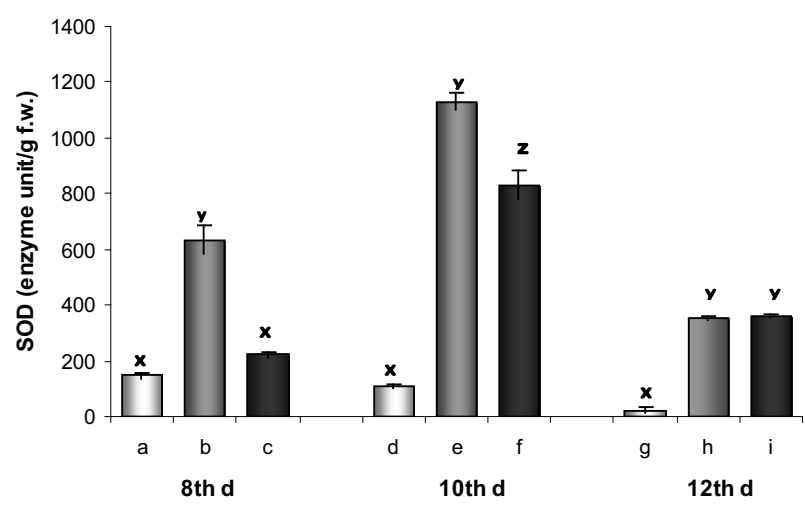

Fig. 2. Effects of $\mathrm{CuSO}_{4}$ at different concentrations on the amount of SOD enzyme in the cells of Capsicum annuum L. in different time.

a) Control, b) $0.1 \mathrm{mM} \mathrm{CuSO}_{4}$, c) $0.2 \mathrm{mM} \mathrm{CuSO}_{4}$ day 8 ; d) Control, e) $0.1 \mathrm{mM} \mathrm{CuSO}_{4}$, f) $0.2 \mathrm{mM} \mathrm{CuSO}_{4}$ day 10 ; g) Control, h) $0.1 \mathrm{mM} \mathrm{CuSO}$, i) $0.2 \mathrm{mM} \mathrm{CuSO}_{4}$ day 12 Vertical bars represent $\mathrm{SE}(\mathrm{n}=4)$. Same letters are not significantly different at $\mathrm{p}<0.05$ on each treatment day (Tukey test)

and catalase (CAT)) $[6,7]$. The rapid inducibility of some of these enzymes makes them early and sensitive indicators of heavy metal toxicity [31].

SOD enzyme activity increased in the treatment groups compared to the control in all treatment days. The highest increases were observed with $431.95 \%$ on day 8 , $1,027.65 \%$ on day 10 at $0.1 \mathrm{mM} \mathrm{CuSO}_{4}$, and with $1,587.44 \%$ on day 12 at $0.2 \mathrm{mM} \mathrm{CuSO}_{4}$ (Fig. 2).

Thounaojam et al. [32] determined that SOD activity increases by $62.85 \%$ and $64.58 \%$ at $100 \mu \mathrm{M} \mathrm{Cu}$ with respect to control in shoots and roots, respectively, after the first day of recording when exposed to $100 \mu \mathrm{M} \mathrm{Cu}$. Their results showed that the levels of SOD induced in response to $\mathrm{Cu}$ stress differ at different $\mathrm{Cu}$ concentrations.

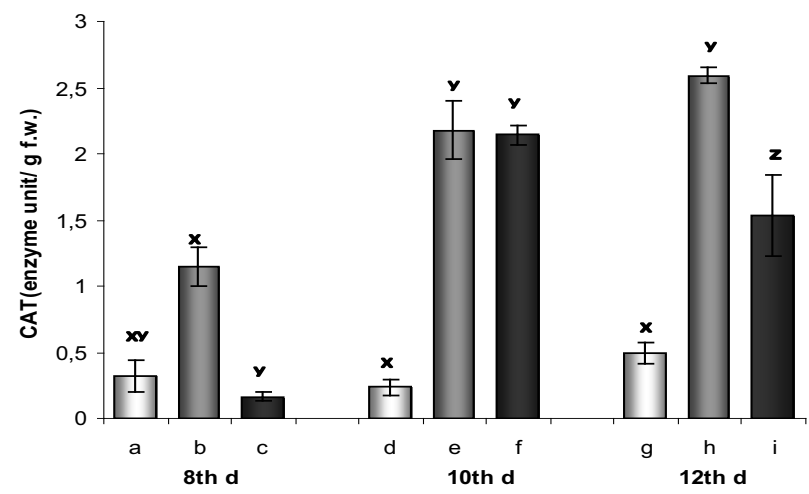

Fig. 3. Effects of $\mathrm{CuSO}_{4}$ at different concentrations on the amount of CAT enzyme in the cells of Capsicum annuиm L. in different time.

a) Control, b) $0.1 \mathrm{mM} \mathrm{CuSO}_{4}$, c) $0.2 \mathrm{mM} \mathrm{CuSO}$ - day 8; d) Control, e) $0.1 \mathrm{mM} \mathrm{CuSO}_{4}$, f) $0.2 \mathrm{mM} \mathrm{CuSO}_{4}$ day 10; g) Control, h) $0.1 \mathrm{mM} \mathrm{CuSO}$, i) $0.2 \mathrm{mM} \mathrm{CuSO}_{4}$ day 12 . Vertical bars represent SE $(n=4)$. Same letters are not significantly different at $p<0.05$ on each treatment day (Tukey test)
Treatments with $0.1 \mathrm{mM} \mathrm{CuSO}_{4}$ were more effective than other treatments in increasing CAT enzyme activity. The highest value was $2.593 \mathrm{eu} / \mathrm{g}$ f.w. in treatment day 12 . CAT activity decreased only at $0.2 \mathrm{mM} \mathrm{CuSO}_{4}$ on day 8 (48.92\%) compared to the control (Fig. 3). Similarly, $\mathrm{Cu}$ stimulated the capacity of catalase and ascorbate peroxidase in Phaseolus vulgaris L. [33].

Devi and Prasad's [34] study supports our results. $\mathrm{Cu}$ ( 2 and $4 \mu \mathrm{M}$ ) considerably increased the activities of ascorbate peroxidase, catalase, and superoxide dismutase. The extent of increase with $4 \mu \mathrm{M} \mathrm{Cu}$ was lower compared to $2 \mu \mathrm{M} \mathrm{Cu}$ for catalase and superoxide dismutase in Ceratophyllum demersum L. Also, stress due to $\mathrm{Cu}$ toxicity resulted in an increase in total catalase and superoxide dismutase activity and a simultaneous induction of $S o d$ and Cat gene expression in Prunus cerasifera [35] and Astragalus neo-mobayenii [36]. During the exposure of plants to excess $\mathrm{Cu}$, the antioxidant defense system helped the plant to protect itself from damage.

Plant secondary metabolites are formed from glucose metabolism intermediated by the shikimic, acetate, and aminoacid pathways [37]. A range of physiological and ecological functions have been reported for these natural products, such as hormone regulation, organogenesis, plant defence against biotic and abiotic agents, chemical signalling to guide pollinators or fruit dispensers, and plant \pm microorganism symbiosis [38-41].

There have been many reports of induced accumulation of phenolic compounds in plants treated with high concentrations of metals $[1,42,43]$. Antioxidant action of phenolic compounds is due to their high tendency to chelate metals. Phenolics possess hydroxyl and carboxyl groups and are able to bind particularly iron and copper [44]. The roots of many plants exposed to heavy metals exude high levels of phenolics [45].

Total phenolic contents increased at all treatments groups in all days to the control. It increased with increasing con-

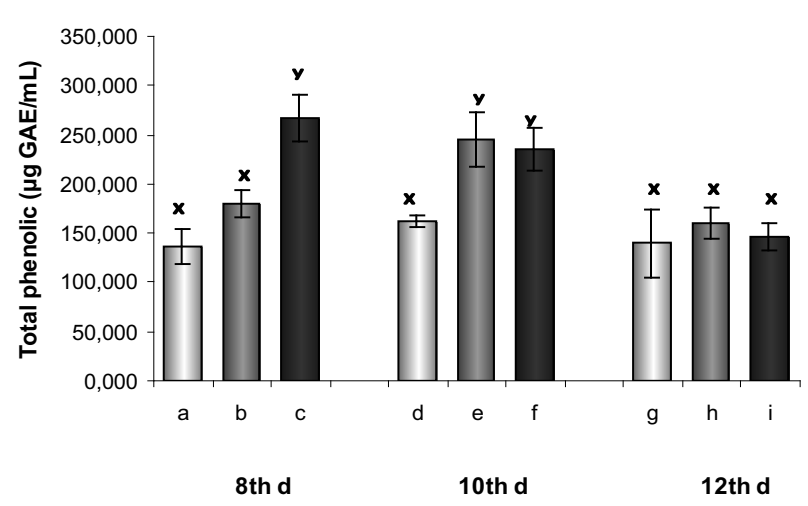

Fig. 4. Effect of $\mathrm{CuSO}_{4}$ at different concentrations on the amount of total phenolic contents in the cells of Capsicum annuum L. in different time.

a) Control, b) $0.1 \mathrm{mM} \mathrm{CuSO}$, c) $0.2 \mathrm{mM} \mathrm{CuSO}_{4}$ day 8; d) Control, e) $0.1 \mathrm{mM} \mathrm{CuSO}$, f) $0.2 \mathrm{mM} \mathrm{CuSO}_{4}$ day 10; g) Control, h) $0.1 \mathrm{mM} \mathrm{CuSO}_{4}$, i) $0.2 \mathrm{mM} \mathrm{CuSO}_{4}$ day 12 . Vertical bars represent $\mathrm{SE}(\mathrm{n}=4)$. Same letters are not significantly different at $\mathrm{p}<0.05$ on each treatment day (Tukey test) 
centrations of $\mathrm{Cu}$ on day 8. The highest value is 266.665 $\mu \mathrm{g} \mathrm{GAE} / \mathrm{mL}$ at $0.2 \mathrm{mM} \mathrm{CuSO}_{4}$ on day $8,244.924 \mu \mathrm{g}$ $\mathrm{GAE} / \mathrm{mL}$ at $0.1 \mathrm{mM} \mathrm{CuSO}_{4}$ on day 10 , and $159.560 \mu \mathrm{g}$ GAE/mL at $0.1 \mathrm{mM} \mathrm{CuSO}_{4}$ in on day 12 (Fig. 4). Similarly, total phenolic contents increased with $\mathrm{Cu}$ treatments compared to the control in Raphanus sativus [46] and Withania somnifera [47].

Phaseolus vulgaris exposed to $\mathrm{Cd}$ acccumulated soluble and insoluble phenolic, and Phyllantus tenellus leaves contain more phenolics than control plants after being sprayed with $\mathrm{Cu}$ sulphate [48]. An increase of phenolic correlated to the increase in activity of enzymes involved in phenolic compounds metabolism was reported, suggesting de novo synthesis of phenolics under heavy metal stress [1].

\section{Conclusions}

Since $\mathrm{Cu}$ is both an essential cofactor and a toxic element involving a complex network of metal trafficking pathways, different strategies have evolved in plants to appropriately regulate its homeostasis as a function of the environmental $\mathrm{Cu}$ level. Such strategies must prevent accumulation of the metal in the freely reactive form (metal detoxification pathways) and ensure proper delivery of this element to target metalloproteins. This study demonstrated that Capsicum annuum L. is quite tolerant to $\mathrm{Cu}$ and mobilizes catalase, superoxide dismutase, and phenolic compounds in order to mitigate $\mathrm{Cu}$-stress damages. Phenolics may inactivate iron ions by chelating and additionally suppressing the superoxide-driven Fenton reaction, which is believed to be the most important source of ROS. So, some antioxidant enzymes (superoxide dismutase, catalase, etc.) may activate.

\section{References}

1. MICHALAK A. Phenolic compounds and their antioxidant activity in plants growing under heavy metal stress. Pol. J. Environ. Stud. 15, (4), 523, 2006.

2. ALAOUI-SOSSÉ B., GENET P., VINIT-DUNAND F., TOUSSAINT M. L., EPRON D., BADOT P. M. Effect of $\mathrm{Cu}$ on growth in cucumber plants (Cucumis sativus) and its relationships with carbohydrate accumulation and changes in ion contents. Plant Science. 166, (5), 1213, 2004.

3. YRUELA I. Cu in plants. Brazilian J. Plant Physiol. 17, (1), $145,2005$.

4. ELSTNER E.F., WAGNER G.A., SCHUTZ W. Activated oxygen in green plants in relation to stress situations. In Current topics in plant biochemistry and physiology: Proceedings of the Plant Biochemistry and Physiology Symposium held at the University of Missouri, Columbia (USA), 1988.

5. MAKSYMIEC W. Effect of $\mathrm{Cu}$ on cellular processes in higher plants. Photosynthetica. 34, (3), 321, 1997.

6. LUNA C.M., GONZÁLEZ C.A., TRIPPI V.S. Oxidative damage caused by an excess of $\mathrm{Cu}$ in oat leaves. Plant Cell Physiol. 35, (1), 11, 1994.
7. WANG H., SHAN X.Q., WEN B., ZHANG S., WANG Z.J. Responses of antioxidative enzymes to accumulation of $\mathrm{Cu}$ in a $\mathrm{Cu}$ hyperaccumulator of Commoelina communis. Arch. Environ. Con. Tox. 47, (2), 185, 2004.

8. KHAN H., SIDDIQUE I., ANIS M. Thidiazuron induced somatic embryogenesis and plant regeneration in Capsicum annuum. Biol. Plantarum. 50, (4), 789, 2006.

9. CHOMCHALOW N. Spice Production in Asia-An Overview. In IBC Asian Spice Markets Conference, 27-28, Singapore, 1996.

10. PALEVITCH D., CRAKER L.E. Nutritional and medicinal importance of red pepper (Capsicum spp.). J. Herbs Spices Med. Plants. 3, 55, 1995.

11. DAOOD H.G., VINKLER M., MARKUS F., HEBSHI, E.A., BIACS, P.A. Antioxidant vitamin content of spice red pepper (paprika) as affected by technological and varietal factors. Food Chem. 55, 365, 1996.

12. KRINSKY N.I. The biological properties of carotenoids. Pure Appl. Chem. 66, 1003, 1994.

13. MATSUFUJI H., NAKAMURA H., CHINO M., TAKEDA M. Antioxidant activity of capsantin and the fatty acid esters in paprika (Capsicum annuum). J. Agr. Food Chem. 46, 3468, 1998.

14. SUKRASNO N., YEOMAN M.M. Phenylpropanoid metabolism during growth and development of Capsicum frutescens fruits. Phytochemistry. 32, 839, 1993.

15. MATERSKA M., PERUCKA I. Antioxidant activity of the main phenolic compounds isolated from hot pepper fruit (Capsicum annuum L.). J Agr. Food Chem. 53, (5), 1750, 2005.

16. USTUN A.S. Investigation of the causes of physiological and biochemical resistance to root rot desease (Phyhophtora Capsici Leon.) in pepper. $\mathrm{PhD}$ thesis, University of Ankara, Institute of Science and Technology, Ankara, 1991.

17. MARINGONI A.C., KIMATI H. Characterization of pathogenic Xanthomonas campestris pv. vesicatoria and hydrolysis of starch in pepper and tomato. Fitopatologia Brasileira 12, 325, 1987.

18. KIMURA O. Chili breeding for resistance to bacterial pustule. Informe Agropecuário 10, 41, 1984.

19. MIRIK M. Defining the pepper bacterial spot factor Xanthomonas campestris pv. vesicatoria and biological control opportunities with plant growth regulators rhizo-bacteria. $\mathrm{PhD}$ thesis, University of Cukurova, Institute of Science and Technology, Cukurova, 162, 2005.

20. STAVREVA VESELINOVSKA S., ZIVANOVIC J., GOKIK M. Changes of some biochemical and physiological parameters in Capsicum annuum L. as a consequence of increased concentrations of $\mathrm{Cu}$ and zinc. Ecol. Balk. 2, 7, 2010.

21. MURASHIGE T., SKOOG F. A revised medium for rapid growth and bio-assays with tobacco tissue cultures. Physiol. Plantarum. 15, 473, 1962.

22. Ellialtioglu S., USTUN S., MEHMETOGLU U. Determining of most suitable medium composition to obtain in vitro callus formation of some pepper varieties. II. Kizilirmak International Science Congress, Proceedings of Biology, KKU Faculty of Literature and Sciences, 51-58, Kirikkale, 1998.

23. BRADFORD M. A rapid and sensitive method for quantation of microgram quantities of proteins utilizing the principle of protein dye binding. Anal. Biochem. 72, 248, 1976.

24. BEAUCHAMP C., FRIDOVICH I. Superoxide Dismutase: Improved assay and applicable to acrylamide gels. Anal. Biochem. 44, 276, 1971. 
25. BERGMEYER N. Methods of enzymatic analysis Akademie Verlag, Berlin, 1970.

26. SINGLETON V.L., ROSSI J.A. Colorimetry of total phenolics with phosphomolybdic-phosphotungstic acid reagents. Am. J. Enol. Viticult. 16, 144, 1965.

27. TUKEY J.W. Some selected quick and easy methods of statistical analysis. Trans. of New York Acad. Sci. 88-97, 1954

28. YRUELA I. Cu in plants: acquisition, transport and interactions. Funct Plant Biol. 36, 409, 2009.

29. HOU W., CHEN X., SONG G., WANG Q., CHANG C.C. Effects of $\mathrm{Cu}$ and cadmium on heavy metal polluted waterbody restoration by duckweed (Lemna minor). Plant Physiol. Bioch. 45, (1), 62, 2007.

30. HALLIWELL B., GUTTERIDGE J.M.C. Oxygen toxicity, oxygen radicals, transition metals and disease. Biochem. J. 219, 1, 1984.

31. TEISSEIRE H., GUY V. Cu-induced changes in antioxidant enzymes activities in fronds of duckweed (Lemna minor). Plant Sci. 153, (1), 65, 2000.

32. THOUNAOJAM T.C., PANDA P., MAZUMDAR P., KUMAR D., SHARMA G.D., SAHOO L., SANJIB P. Excess $\mathrm{Cu}$ induced oxidative stress and response of antioxidants in rice. Plant Physiol. Bioch. 53, 33, 2012.

33. WECKX J.E., CLIJSTERS H.M. Oxidative damage and defense mechanisms in primary leaves of Phaseolus vulgaris as a result of root assimilation of toxic amounts of $\mathrm{Cu}$. Physiol. Plantarum, 96, (3), 506, 1996.

34. DEVI S.R., PRASAD M.N.V. Cu toxicity in Ceratophyllum demersum L. (Coontail), a free floating macrophyte: response of antioxidant enzymes and antioxidants. Plant Sci. 138, (2), 157, 1998.

35. LOMBARDI L., SEBASTIANI L. Cu toxicity in Prunus cerasifera: growth and antioxidant enzymes responses of in vitro grown plants. Plant Sci. 168, (3), 797, 2005.

36. KARIMI P., KHAVARI-NEJAD R.A., NIKNAM V., GHAHREMANINEJAD F., NAJAFI F. The effects of excess $\mathrm{Cu}$ on antioxidative enzymes, lipid peroxidation, proline, chlorophyll, and concentration of $\mathrm{Mn}, \mathrm{Fe}$, and $\mathrm{Cu}$ in Astragalus neo-mobayenii. Scientific World Journal, 2012.

37. GEISSMAN T.A., CROUT D.H.G. Organic chemistry of secondary metabolism. San Francisco, USA: Freeman, Cooper \& Company, 1969.
38. CURIR P., VANSUMERE C.F., TERMINI A., BARTHE P., MARCHESINI A., DOLCI M. Flavonoid accumulation is correlated with adventitious root formation in Eucalyptus gunii Hook micropropagated through axillary bud stimulation. Plant Physiol. 92, 1148, 1990.

39. VAN TUNEN A.J., MOL J.N.M. Control of flavonoid synthesis and manipulation of fower colour. In: Blackie DG, ed. Developmental regulation of plant gene expression, Plant Biotechnology Series. New York: Chapman and Hall, 1991.

40. VOGT T., POLLAK P., TARLYN N., TAYLOR L.P. Pollination and wound-induced kaempferol accumulation in Petunia stigmas enhances seed production. Plant Cell. 6, 11, 1994.

41. TURLINGS T.C.J., LOUGHRIN J.H., MCCALL P.J., ROSE U.S.R., LEWIS W.J. How caterpillar-damaged plants protect themselves by attracting parasitic wasps. Proceedings of the National Academy of Sciences, USA. 92, 4169-4174, 1995.

42. IZBIAŃSKA K., ARASIMOWICZ-JELONEK M., DECKERT J. Phenylpropanoid pathway metabolites promote tolerance response of lupine roots to lead stress. Ecotox. Environ. Safe. 110, 61, 2014.

43. SAKIHAMA Y., COHEN M.F., GRACE S.C., YAMASAKI H. Plant phenolic antioxidant and prooxidant activities: phenolics-induced oxidative damage mediated by metals in plants. Toxicology, 177, (1), 67, 2002

44. JUNG C.H., MAEDER V., FUNK F., FREY B., STICH E.R.H., FROSS ERD E. Release of phenols from Lupinus albus $\mathrm{L}$. roots exposed to $\mathrm{Cu}$ and their possible role in $\mathrm{Cu}$ detoxification. Plant Soil. 252, 301, 2003.

45. WINKEL-SHIRLEY B. Biosynthesis of flavonoids and effects of stress. Curr. Opin. Plant Biol. 5, 218, 2002.

46. SGHERRI C., COSI E., NAVARI-IZZO F. Phenols and antioxidative status of Raphanus sativus grown in $\mathrm{Cu}$ excess. Physiol. Plantarum. 118, (1), 21, 2003.

47. KHATUN S., ALI M.B., HAHN E.J., PAEK K.Y. Cu toxicity in Withania somnifera: Growth and antioxidant enzymes responses of in vitro grown plants. Environ. Exp. Bot. 64, (3), 279, 2008.

48. MITHOFER A., SCHULZE B., BOLAND W. Biotic and heavy metal stress response in plants: evidence for common signals. FEBS Lett. 566, 1, 2004. 
